djelu Ivane Brlić-Mažuranić (Zvonimir Diklić). Branko Pilaš obrazlaže kako je Skokov urednički rad u časopisu Radost djelovao na njegov antologičarski habitus, a Dubravka Težak analizira knjigu Ezopuševe basne pohorvačene koja je pretisak Kristijanovićevih Ezopuševih basni iz 1843. godine iz popularnoga kalendara „Danica zagrebečka“, a koju je J. Skok priredio. Riječ je, prema D. Težak, o prvome kritičkome izdanju Kristijanovićeva djela, $\mathrm{s}$ fonemskom i grafemskom transliteracijom te objašnjenjima kajkavskih riječi i fraza u zatečenome gramatičkome obliku i kontekstualnome značenju. Drugi dio knjige donosi i pretisak naslovnice kalendara za svako godište, bogat izbor ilustracija starih izdanja Ezopovih basana. Treći dio knjige donosi dva Skokova eseja, jedan o Ezopu, a drugi o Ignacu Kristijanoviću. O toj knjizi priložen je i esej Branke Hlevnjak koji je objavljen u Hrvatskome slovu, kao i tekst Željke Vegha iz Kola. Dragutin Rosandić temeljito je raščlanio Skokovu ,poetiku“ stvaranja književnih čitanki za osnovnu školu. Posljednju studiju u ovome dijelu čini ona Miroslava Šicela, „Šenoina 'Kanarinčeva ljubovca' u interpretaciji Jože Skoka“. Usredotočuje se na dva ishodišta i polazne točke iz kojih Skok kreće u analizu: njegov analitičko-kritički odnos prema tradicionalnoj i suvremenoj hrvatskoj novelistici i razlaganje vlastite teorije poetike novele.

Naslov je posljednjega, petoga dijela „Biografski, autobiografski i bibliografski portret autora“. Autor Joža Skok dvostruki je dobitnik nagrade za životno djelo, a poglavlje koje donosi njegov portret počinje iscrpnim životopisom u kojemu Božica Pažur ne zaboravlja niti jednu važniju činjenicu. Potom slijedi rad Marijana Kraša „Dobriša Cesarić i Gustav Krklec. Početak proljeća - Crni kos“ posvećen Joži Skoku kao dugogodišnjemu proučavatelju tih dvaju književnika. Iza toga slijede razgovori Denisa Peričića, Božice Pažur, Ivana Rodića i Mire Čurić s Jožom Skokom.

Na kraju ove pozamašne knjige (510 str.) nalazi se „Bibliografija“ Jože Skoka tematski raspoređena po vrsti radova, od knjiga studija, eseja i kritičko-teorijskih rasprava, preko antologija kajkavske književnosti i hrvatske dječje književnosti, do metodičkih eseja i priručnika i hrvatskih čitanki za osnovnu i srednju školu. Na kraju knjige nalaze se abecedni popis autora priloga i priređivačke napomene.

Svi ti podatci već dovoljno govore o kakvu je čovjeku riječ u osobi pokojnoga profesora Jože Skoka. Lijepo je da je dočekao ovakvo jedno izdanje. I da ga je ono ispratilo na putu prema vječnosti.

Diana Zalar

\title{
Roman o kojem se (još) uvijek ima što reći
}

Berislav Majhut. 2016. U carevoj misiji ili sto godina čudnovatih nezgoda. Zagreb: ArTresor naklada. 326 str. ISBN 978-953-6522-86-6

DOI: 10.21066/carcl.libri.2017-06(02).0016

Studija Berislava Majhuta Ucarevoj misiji ili sto godina čudnovatih nezgoda posvećena je najpoznatijemu i najčitanijemu romanu hrvatske dječje književnosti - Čudnovatim zgodama šegrta Hlapića Ivane Brlić-Mažuranić. Unatoč činjenici da je roman bio u središtu interesa mnogih književnih teoretičara i povjesničara, on i dalje ostaje zanimljivim izvorom proučavanja, osobito u novim kontekstima koje donosi suvremeno vrijeme u kojem se redefiniraju stari stavovi i u kojem se na djelo i njegovu recepciju u kontekstu suvremenih čitatelja i medija gleda na nove načine. 
Majhutova studija ima četrnaest poglavlja koja obuhvaćaju vrijeme od nastanka romana i konteksta njegova nastanka do puta koji je prelazio tijekom stoljeća svojega postojanja, a obuhvaća prikaz i revidiranje iščitavanja romana u različitim ideološkim i književnoteorijskim ključevima, prikaz prenošenja u druge medije, analize ilustracija i ulogu koju Hlapić danas ima u hrvatskoj kulturi i društvu. Jedno od važnih vrela za donošenje zaključaka Majhutu je bogata korespondencija koju je Ivana Brlić-Mažuranić vodila i iz koje izvlači korisne informacije i zaključke. Autor naglašava da je studija oblikovana modularno kako bi se obuhvatili različiti aspekti proučavanja romana, a čitati se može s obzirom na fokuse zanimanja.

U prvome poglavlju autor istražuje obiteljske, društvene i povijesno-političke okolnosti 1912., godine u kojoj je roman napisan. Svoje zaključke temelji na korespondenciji Ivane Brlić-Mažuranić s članovima obitelji iz koje rekonstruira političku, ali i obiteljsku okolinu 1912. godine.

U drugome poglavlju analiziraju se književnopovijesne i nakladničke aktivnosti objavljivanja Čudnovatih zgoda šegrta Hlapića. Majhut i u tom poglavlju iz autoričine korespondencije rekonstruira pisanje i dovršavanje romana te obiteljske okolnosti koje su to pratile (nedostatak vremena i briga o kućanstvu koju Brlić-Mažuranić nastoji naglasiti). Iz njezinih se pisama vidi da Hlapića smatra dobrim djelom i nagađa da bi mogao biti dobro prihvaćen. Prikazi nakladničkih i književnopovijesnih okolnosti u godinama pisanja i objavljivanja romana vrlo su bitni jer su promjene koje su se zbile zbog smrti Tomislava Ivkanca 1912. i dolaska Josipa Škavića, koji je smatrao da djeci treba nuditi umjetnički vrijednu literaturu, na mjesto urednika dječjih izdanja Hrvatskoga pedagoško-književnoga zbora (HPKZ-a) vjerojatno utjecale na autoričinu odluku o pisanju toga romana, koji je i ranije nudila HPKZ-u. Korespondencija još otkriva i reakcije Ivane Brlić-Mažuranić na izdavačeve korekcije teksta, kao i prve čitateljske i kritičarske reakcije. Majhut piše o značenju tih prvih recenzija, prije svega Matoševe, a piše i o podatcima o prodaji, koji upućuju na veliku popularnost djela odmah nakon izlaska.

Treće poglavlje donosi analizu izdanja Šegrta Hlapića objavljenih u Hrvatskoj u dohvatu volje Ivane Brlić-Mažuranić. Majhut navodi da se radi o trima izdanjima: o prvome, HPKZ-ovu izdanju iz 1913., drugome, Kuglijevu izdanju iz 1922. i trećem, Horvatovu izdanju iz 1941. U svim se navedenim izdanjima mogu uočiti uredničke intervencije koje su utjecale na razumijevanje i interpretaciju Šegrta Hlapića. Majhut analizira rubne elemente romana kako bi kontekstualizirao vrijeme radnje i upozorava na neprimjereno mjesto koje je Šegrt Hlapić imao u hrvatskoj dječjoj književnosti punih stotinu godina jer je vrijeme radnje bilo smještano u suvremenost izdavanja romana, zbog čega djelo nije predstavljano kao pripovijest iz prošlosti. Majhut pokazuje da je radnja romana smještena u osamdesete godine devetnaestoga stoljeća, u vrijeme autoričina djetinjstva.

Majhut u četvrtome poglavlju proučava povijest recepcije Čudnovatih zgoda šegrta Hlapića i razlikuje tri razdoblja recepcije romana: 1. Matoševu ocjenu, 2. preispitivanje Šegrta Hlapića u književnim kontekstima od 30-ih do 60-ih godina 20. stoljeća i 3. Crnkovićevo smještanje Šegrta Hlapića u kontekst dječje književnost kao dječjega romana. Tek Crnkovićevim smještanjem Šegrta Hlapića u dječju književnost i tezom da je to prvi hrvatski dječji roman (što će se kasnije revidirati), Hlapić dobiva svoje mjesto u pravome kontekstu. Majhut navodi da devedesete godine 20. stoljeća, iako protkane izvanknjiževnim 
događajima i promjenama, ne donose novosti po pitanju znanstvene recepcije $\check{C}$ udnovatih zgoda šegrta Hlapića, osim promatranja romana i u religijskome kontekstu. Navodeći daljnje „nezgode“ koje su se događale u vezi s istraživanjem i recepcijom Šegrta Hlapića, Majhut u petome poglavlju proučava načine na koje se Hlapić vrsno određivao i zaključuje da se pravo vrsno određenje može dati njegovim smještanjem u kontekst vremena nastanka i otkrivanjem književnih postupaka i repertoara koji su autorici u to vrijeme bili poznati.

U šestome poglavlju naslovljenome, Šegrt Hlapić i književni srodnici i susjedi“ Majhut predstavlja poticaje za pisanje Čudnovatih zgoda šegrta Hlapića o kojima je autorica pisala češkomu nakladniku 1931. U tom se poglavlju analiziraju sličnosti i razlike s Hlapićevim prethodnicima, a navode se i romani koji su mogli nastati po uzoru na Čudnovate zgode šegrta Hlapića, odnosno oni kojima je taj roman bio inspiracija i koji donose varijacije Hlapićeve teme. Godina 1913. važna je za hrvatsku dječju književnost jer su tada objavljena dva važna djela - Čudnovate zgode šegrta Hlapića Ivane Brlić-Mažuranić i Bijeli jelen Vladimira Nazora. Usporedbom tih djela Majhut zaključuje da su potpuno različita vrijednostima i odnosom prema tradiciji.

Analizom dobi čitateljske publike Čudnovatih zgoda šegrta Hlapića u sedmome poglavlju prikazuje se na koji se način tijekom povijesti određivala namjena romana implicitnim čitateljima s obzirom na kritičare i uredničku izdavačku politiku. U osmome se poglavlju grafičkim prikazom predočava kojim se predlošcima koristilo za izdanja $\breve{S}$ grta Hlapića nakon autoričine smrti. Majhut analizira i hrvatska i inozemna izdanja te zaključuje da je naviše izdanja nastalo prema Kuglijevu izdanju iz 1922. Ujedno i grafički prikazuje učestalosti izdanja, što nas upućuje na recepciju djela tijekom stoljeća njegova postojanja.

Na svojem stogodišnjem putu Hlapić je prolazio preinake i cenzure, što se analizira u devetome poglavlju monografije. Preinake se mogu vidjeti od prvoga izdanja urednika Škavića u kojemu ima 1500 izmjena u odnosu na rukopis, do preinaka koje nisu bile u skladu s komunističkom ideologijom nakon 2. svjetskoga rata. Ako bi cenzura i izostala u samome tekstu, onda je roman interpretiran u drugome ključu izostavljajući kršćanske vrijednosti. Majhut u devetome poglavlju monografije obrađuje dramatizacije Šegrta Hlapića pri čem se zadržava na prvim dvjema dramatizacijama iz 1931. i 1934., koje su nastale za života Ivane Brlić-Mažuranić i u čijem je nastanku i ona sama sudjelovala. U tom poglavlju donose se kritike i osvrti na izvedbe Strozzijeve adaptacije Čudnovatih zgoda šegrta Hlapića i autoričine reakcije na navedenu dramatizaciju.

Nakon razmatranja prvih dramatizacija, Majhut u desetome poglavlju proučava pojavnost Šegrta Hlapića u drugim medijima za života Ivane Brlić-Mažuranić, na primjer neuspjeli pokušaj filmske ekranizacije i proboja Hlapića u svijet. Dva su poglavlja monografije, dvanaesto i trinaesto, posvećena proučavanju ilustracija, a zasebno se proučavaju ilustracije u izdanjima objavljenima za života Ivane Brlić-Mažuranić i u kasnijim izdanjima. Iz korespondencije se tako otkriva koliko je autorici bila važna ilustracija u Šegrtu Hlapiću te koliko se brinula zbog činjenice da se ilustriranje nije odvijalo po njezinoj volji i zamisli. Majhut analizira i omote knjiga koji određuju smjer kojim valja uputiti čitateljeva očekivanja i rješenja kojima su se neki ilustratori koristili i koja su utjecala na neformiranje Hlapićeva vizualnoga identiteta u prvim izdanjima za autoričina života, a koja su utjecala i na kasnije ilustratore Čudnovatih zgoda šegrta Hlapića.

Proučavajući ilustracije u izdanjima nakon smrti Ivane Brlić-Mažuranić, Majhut zaključuje da Hlapić nije uspio ostvariti svoj vizualni identitet i osigurati trajnu 
prepoznatljivost svojega lika, ali to može biti i prednost pri proučavanju različitih ilustratorskih rješenja i praksi. Upravo proučavanje ilustracija daje komentar na tekst i samoga ilustratora, urednika i nakladnika, ali govori i o čitateljskoj publici. Uz ilustracije u romanu Majhut analizira i omotne ilustracije i pripovjednu liniju koju žele naglasiti: onu pustolovnu ili priču o izgubljenome djetetu. Analizira se i problem citiranja ilustracija, smještaj i problemi konzistencije lika, ambijenta i rekvizita te pogreške ilustratora u iščitavaju teksta i razlike teksta i ilustracija. U posljednjem poglavlju koje nosi naslov „Hlapić 2013.“ govori se o stanju i mjestu Hlapića u suvremenoj kulturi, uzimajući u obzir samo neke vidove te kulture. Proučavanjem pojavnosti sintagme ,šegrt Hlapić“ u hrvatskome tisku proširuje se kontekst razmatranja šegrta Hlapića na cijelo hrvatsko društvo.

Ova studija rasvjetljava mnoga mjesta u romanu i njegovoj recepciji te redefinira starija viđenja, kao i čitanje Hlapića u kontekstima koji do sada nisu istraživani, što ju čini vrijednim prinosom proučavanju konteksta nastanka romana i puta koji je prešao u stotinu godina svojega postojanja.

Vedrana Živković Zebec 